\title{
Suitability of the HIV/AIDS Control Program in the HIV/AIDS Control Policy in Banjarmasin to Achieve
} "Getting to Zero"

\author{
Nana Noviana ${ }^{1}$, Sri Suwitri ${ }^{2}$, Bambang Supriyono ${ }^{3}$, Sutopo Patria Jati ${ }^{4}$ \\ ${ }^{1}$ Regional Research and Development Agency, South Kalimantan Province, Indonesia \\ ${ }^{2}$ Doctoral Public Administration, Diponegoro University, Semarang, Indonesia \\ ${ }^{3}$ Brawijaya University, Surabaya, Indonesia \\ ${ }^{4}$ Public Health Faculty, Diponegoro University, Semarang, Indonesia \\ gadysnoviana@gmail.com
}

\begin{abstract}
Increasing HIV/AIDS infection has made Banjarmasin City government increasingly worried, so that the realization of policy implementation is needed to solve the problem. Because if the problem of HIV/AIDs is allowed to have an impact on regional development, budgeting and also have an impact on poverty. Based on these, this research is focused on the suitability of the program with the needs of the community in implementing HIV/AIDS control policies. This study aims to describe, analyze and interpret matters relating to the suitability of the program with the need to implement policies in an effort to control HIV/AIDS in the city of Banjarmasin. The qualitative research method uses a descriptive approach based on a public policy perspective. This study seeks to present the empirical facts of the Banjarmasin City government's naturalistic actions and reveal hidden values. So it is expected to illustrate the phenomenon of the implementation of government policies regarding the suitability of the program with the need to control HIV/AIDS in the city of Banjarmasin. Based on the results of the study, it can be concluded that the suitability of the program with the needs in the Implementation of HIV/AIDS Control Policy in the city of Banjarmasin has not run in accordance with the contents of the local regulations. Incompatibility of HIV/AIDS control programs with community needs in the city of Banjarmasin and the lack of stakeholder support and coordination in efforts to control HIV/AIDS based on these findings and the suggestion of this research, it will help the Banjarmasin City Government take HIV/AIDS control policies that are oriented towards the needs of the people in Banjarmasin City. This research also aims to contribute to the public policy scientific literature and individuals involved in controlling HIV/AIDS in the City of Banjarmasin.
\end{abstract}

Keywords: Getting to zero, HIV/AIDS Control Program, HIV/AIDS, HIV/AIDS Control Policy Regional Regulation Banjarmasin.

\section{Introduction}

The role of policy implementation will continue to be needed in the realization of practices to solve social problems that will influence the formation and opinion of policies. To realize good public policies, policy implementation must be appropriate and able to meet the needs of the community. Its implementation is mentioned in the book Public Policy, Parsons (1997). Limited efforts for prevention and implementation services at various provincial and district levels influence the implementation of HIV/AIDS control policies. The increase in HIV/AIDS infections has made the government increasingly worried that the role of policy implementation will continue to be needed in the realization of practices to solve it because it will have an impact on regional development, budgeting and also have an impact on poverty. To realize this goal, it is necessary to do various health efforts such as policies regarding the Program made by the Banjarmasin City Government on Regional Regulation No.11 of 2012 on controlling HIV/AIDS. With the HIV / AIDS Control Program, it must be able to prevent the number of HIV infections and improve the quality of life of the people. Most AIDS programs do not specifically see and overcome obstacles to HIV/AIDS services. Providers of HIV/AIDS control services must be carried out optimally to achieve comprehensive and sustainable services according to the needs of the community. To achieve comprehensive and sustainable HIV/AIDS control services, the service program provided to the community must be in accordance with the needs of the community. Thus, the services carried out by the government can touch directly to the public. In accordance with this research, the theory of Goerge C. Edwards III and Ira Sharkansky in Suwitri et al (2009) states that public policy is government action in the form of government programs to achieve goals or targets. In this case the Banjarmasin City Government's actions in implementing HIV/AIDS control with the aim of suppressing the incidence of HIV/AIDS in Banjarmasin City with the existence of regional regulations governing HIV/AIDS control in the city of Banjarmasin it is hoped that it can accelerate the success. 


\section{Research Methods}

This research is a qualitative study using a descriptive approach based on a public policy perspective. System analysis method from policy data, guidelines, and implementation of HIV / AIDS control programs in the city of Banjarmasin this study seeks to present empirical facts of the action of the Banjarmasin City government in a naturalistic way and also seeks to uncover hidden values so that it is expected to be able to illustrate the phenomenon of the suitability of HIV / AIDS control programs with community needs in implementing HIV / AIDS control policies in Banjarmasin City. The selection of informants is based on certain considerations according to the information needs needed taken from people who better understand the implementation of HIV / AIDS prevention programs in the city of Banjarmasin, namely: AIDS Prevention Commission (KPA), Banjarmasin City Health Office, Banjarmasin City Social Service, City Education Office Banjarmasin, Banjarmasin City Tourism Office, Puskesmas (Counselors), NGOs, PLWHA, Community (Community leaders). Data collection techniques using interviews using interview guidelines as a guide in conducting interviews. The observation method in this study is connected together to enrich the research by presenting additional data to support the data obtained from the interview. Data collection techniques using interviews using interview guidelines as a guide in conducting interviews. This observation activity is expected to get a more detailed and real picture of the process of implementing HIV / AIDS control policies in the city of Banjarmasin. Documentation is used to obtain secondary data in the form of written data relating to HIV / AIDS control programs that have been carried out in the form of decisions, documents, archival guidelines, books, data, report relating to research.

\section{Results}

Table 1: HIV/AIDS Control Policy

\begin{tabular}{|c|c|c|c|}
\hline Policy & $\begin{array}{l}\text { Research Results Data } \\
\text { In-depth Interviews }\end{array}$ & Review the Document & Analysis \\
\hline $\begin{array}{l}\text {-Regional Regulation } \\
\text { Number } 11 \text { of } 2012 \\
- \text { Minister of Health } \\
\text { Regulation Number } 21 \\
\text { Year } 2013 \\
- \text { Regulation of the } \\
\text { Minister of Social } \\
\text { Affairs Number } 6 \text { Year } \\
2018 \text { Socialization of } \\
-\quad \text { Regional Regulation } \\
\text { Number } 11 \text { of } 2012\end{array}$ & $\begin{array}{l}\text { Most respondents stated } \\
\text { that the policy that } \\
\text { became a reference in the } \\
\text { implementation of HIV / } \\
\text { AIDS control was from } \\
\text { the ministry of health, } \\
\text { while for local regulations } \\
\text { there was no socialization } \\
\text { or guardianship. }\end{array}$ & $\begin{array}{l}\text { From the results of the } \\
\text { document review, there } \\
\text { was no mayor's regulation } \\
\text { as a reference for } \\
\text { implementing HIV / AIDS } \\
\text { control }\end{array}$ & $\begin{array}{l}\text { Based on the results of } \\
\text { interviews and } \\
\text { document review, the } \\
\text { policy used to control } \\
\text { HIV / AIDS is Permenkes } \\
\text { No. } 21 \text { of 2013, and no } \\
\text { guardian was found to } \\
\text { support the } \\
\text { implementation of the } \\
\text { program }\end{array}$ \\
\hline
\end{tabular}

Source: Interview (processed by researchers), 20

Table 1 can be seen that the results of research using the interview method and document review on the implementation of HIV / AIDS prevention policies in the city of Banjarmasin is the Banjarmasin City Health Office implementing an HIV / AIDS control policy based on the Minister of Health Regulation No. 21/2013, while the Banjarmasin City Social Service is based on Regulation of the Minister of Social Affairs Number 6 Year 2018, while for the Banjarmasin City AIDS Commission carry out activities from the budget of the Office of Health and Foreign and Private Aid. In addition, regional regulation number 11 of 2012 concerning prevention of HIV / AIDS has never been socialized, especially to agencies involved in implementing HIV / AIDS control in the city of Banjarmasin. 
Table 2: Suitability of the HIV/AIDS Control Program

\begin{tabular}{llll}
\hline Policy & $\begin{array}{l}\text { Research Results Data } \\
\text { In-depth Interviews }\end{array}$ & Review the Document & Analysis \\
\hline - HIV / AIDs control & $\begin{array}{l}\text { Based on the results of Based on the review of The HIV / AIDS Control } \\
\text { program }\end{array}$ in werviews with documents that there is Program is not focused \\
Banjarmasin City & $\begin{array}{l}\text { respondents stated that no record of the and does not meet the } \\
\text { the suitability of HIV / implementation of special needs of the risk }\end{array}$ \\
& AIDS control programs is programs for high-risk communities. \\
& not in accordance with communities, namely \\
& the needs of the MSM communities \\
& community and does not \\
& match the facts in the \\
& field.
\end{tabular}
Source: Interview (processed by researchers), 2019

In an effort to achieve policy objectives, the policies offered should be in accordance with the needs of the target group. The policy on HIV / AIDS prevention has been accommodated regarding efforts to provide health services for people at risk of becoming infected with a virus which weakens the human immune system (Human Immunodeficiency Virus), in Presidential Regulation No. 2 of 2018 concerning minimum service standards, which stated that one type of service provided is to people at risk of HIV infection. This Presidential Regulation is clarified in Minister of Health Regulation No. 4 of 2019 concerning technical standards for fulfilling the quality of basic services at minimum service standards in the health sector. In this SPM technical standard in the health sector, it is explained in more detail about the provisions regarding the Types and Quality of Basic Services which are the Obligatory Government Affairs that are entitled to be obtained by every citizen at a minimum.

The control policies offered by the Banjarmasin City Government as stated in Regional Regulation No. 11 of 2012 are efforts that include prevention and control of HIV / AIDS. The health offices together with related agencies carry out an HIV / AIDS control program in the city of Banjarmasin. Almost all members of our community are close to digital media, so it will be very easy to spread information about HIV / AIDS prevention through digital media. This is because the increase in cases of HIV / AIDS every year is increasing significantly. One of the strategic steps taken by the Health Office is to strengthen the AIDS Commission at all levels. Following is the scope of the interview with A from the Banjarmasin City Health Office: "...... Like we said, if the local regulation is implemented, it is white and gray, so we are unclear ... and too broad, the role of the PL in Outreach and Assistance is not comprehensive which results in incompatible with the main tasks and functions of the outreach ...."(Interview 25 February 2019). The following activities are carried out in the HIV / AIDS control program:

Table: 3 HIV/AIDS Control Programs

\begin{tabular}{|c|c|c|c|}
\hline $\begin{array}{l}\text { HIV / AIDS Control } \\
\text { based on Regional } \\
\text { Regulation No.11 of } \\
2012\end{array}$ & $\begin{array}{l}\text { HIV / AIDS Control Program } \\
\text { from the Health Office } \\
\text { Banjarmasin City }\end{array}$ & $\begin{array}{l}\text { Fast Track Response from } \\
\text { the Ministry of Health }\end{array}$ & $\begin{array}{l}\text { Banjarmasin } \\
\text { City AIDS } \\
\text { Commission }\end{array}$ \\
\hline $\begin{array}{l}\text { a. not engaging in } \\
\text { unhealthy and } \\
\text { distorted sexual } \\
\text { relations; } \\
\text { b. loyal to one partner; } \\
\text { c. use condoms for } \\
\text { every sexual contact } \\
\text { who is at risk of } \\
\text { contracting HIV-AIDS } \\
\text { d. transfused blood } \\
\text { must be free of HIV; } \\
\text { e. use of sterile and }\end{array}$ & $\begin{array}{l}\text { 1. VCT \& VCT mobile services } \\
\text {. Knowledge level survey } \\
\text {. High-risk population outreach } \\
\text { l. Mapping of key populations } \\
\text { : Partnership meeting with the } \\
\text { related LP / LS } \\
\text { Promulgation of HIV / AIDS } \\
\text { control } \\
\text { f. ABAT Campaign } \\
\text { l. Increased participation of KPA } \\
\text { and NGOs } \\
\text {. Improve and develop programs }\end{array}$ & $\begin{array}{l}\text { Che combination of intensive } \\
\text { control (comprehensive_in } \\
\text { areas of high prevalence, } \\
\text { including: } \\
\text { Condom } \\
\text { High coverage among key } \\
\text { populations } \\
\text { Pre-exposure prophylaxis } \\
\text { for certain populations } \\
\text { Young women and girls } \\
\text { BLT } \\
\text { Circumcision for men }\end{array}$ & $\begin{array}{l}\text {-Distribution of } \\
\text { Condoms } \\
\text { - HIV } \\
\text { Intervention } \\
\text { Program } \\
\text {-International } \\
\text { coordination } \\
\text {-Coordinate } \\
\text { Management } \\
\text {-Coordination of } \\
\text { Stakeholders }\end{array}$ \\
\hline
\end{tabular}


disposable syringes;

f. use of sterile medical devices;

g. ODHA mothers are obliged to prevent HIV transmission to the babies they are carrying;

h. removal of organs and body tissues must be free of HIV;

Source: Interview (processed by researchers), 2019

Based on the data obtained during the study, the relevant agencies that carry out HIV/AIDS control seem to only carry out routine programs from the previous year's programs. The programs carried out do not seem to be in order of priority, such as the number of people living with HIV/AIDS in the majority of MSM communities, but programs specifically to prioritize HIV/AIDS control by MSM communities by distributing condoms, but condoms that are distributed not to MSM communities but in general.

\section{Discussion}

HIV/AIDS Control Policy: National government HIV / AIDS prevention efforts contained in the National AIDS Strategy 2015-2019 are a reference for HIV / AIDS prevention efforts in the city of Banjarmasin. In addition to the National HIV / AIDS Prevention Strategy, the government is also implementing an accelerated / Fast-track program in the prevention of HIV / AIDS as an intensive and comprehensive prevention effort suitable for areas of high prevalence. The issuance of Presidential Regulation number 76 of 2005 as a commitment of the government in the prevention of HIV / AIDS. The commitment of the government in the prevention of HIV / AIDS can be seen from the formation of the AIDS Commission with the issuance of Presidential Regulation Number 76 of 2005. Although in the course of the policy the changes occurred because they were informed that the validity period of the KPAN (National AIDS Commission) had expired based on Presidential Regulation Number 124 Year 2016 on 31 December 2017. Nonetheless, the efforts to prevent HIV / AIDS by the KPAN continued under the auspices of Ministry of Health in the Director General of P2P Ministry of Health. The National HIV / AIDS Strategy a proof of the government's commitment to tackling HIV / AIDS and this is the Blue Print to fight HIV / AIDS in Indonesia. Therefore, national, provincial and global government policies are the basis for consideration in efforts to prevent HIV / AIDS in the city of Banjarmasin. The response of the Banjarmasin City Government in efforts to prevent HIV / AIDS is by issuing Local Regulation Number 11 of 2012 concerning HIV / AIDS Control in the City of Banjarmasin. The response to the issuance of this Regional Regulation is a top-down policy model because it is assumed to be a government initiative itself and is run by the government (Van and Horn, 1975).

When a policy in the form of government initiative and formulated by the government does not guarantee that the policy that has been made will run well. The implementation of HIV / AIDS control policies in the city of Banjarmasin is inseparable from the national HIV / AIDS prevention and control policy. Efforts to prevent, control and deal with AIDS are mandated in Presidential Regulation No. 75 of 2006 to avoid major health, social, political and economic impacts. This response effort is also contained in the National Strategy and Action Plan for the Prevention of HIV and AIDS 2015-2019 which has the general objective of accelerating 3 zero, namely zero new infections, zero deaths from AIDS, zero stigma \& discrimination. The national HIV / AIDS strategy and plan is a reference for regions to implement HIV / AIDS control and control programs. However, the success of controlling HIV / AIDS in an area will differ depending on the characteristics and conditions of the area. As in the area of Banjarmasin City which is the highest AIDS number from 13 regencies / cities in South Kalimantan Province. From the data of the South Kalimantan Provincial Health Office in 2018, the city area of Banjarmasin has the highest accumulation of AIDS, amounting to 387 people. The increase in HIV / AIDS cases in Banjarmasin City was in response to the Banjarmasin City government by issuing Regional Regulation No. 11/2012 on controlling HIV / AIDS in Banjarmasin City. The existence of this regulation is expected to be a legal umbrella for local governments in implementing HIV / AIDS control efforts 
as an effort to suppress the spread of HIV / AIDS in the city of Banjarmasin. The rate of spread of HIV / AIDS in the city of Banjarmasin has increased from year to year, since Regional Regulation No. 11 of 2012 has been set up until now there has been an increase in the number of cases of HIV / AIDS by 787 people until 2019.

This explains that with the increasing number of people with HIV / AIDS from year to year there are still many HIV / AIDS sufferers who have not yet been identified, this is because the characteristics of HIV / AIDS is an iceberg phenomenon that is identified only on the surface. The health office, AIDS Prevention Commission and NGOs have tried to screen and collect data on people infected with HIV / AIDS, but to detect someone infected with HIV requires a considerable time of about 5-10 years. This means that if someone is infected with HIV then the symptoms of illness will appear in a long period of time. With the increase in HIV / AIDS cases in Banjarmasin City, the government has tried to control HIV / AIDS by making regional regulation number 11 of 2012 on controlling HIV / AIDS in Banjarmasin City, but the implementation of these regional regulations has not been maximized, due to several agencies involved in the regulation the area did not know the local regulation. In an effort to achieve the goal it is not easy, considering the increase in the number of people with HIV / AIDS is increasing and requires a long time until the onset of symptoms. This is because the spread of HIV / AIDS is like an iceberg phenomenon which suggests that there will continue to be an increase in AIDS sufferers because it has not been identified from time to time. The table below will show the number of HIV / AIDS sufferers by age group in Banjarmasin City from 2012 to 2018.

Table 4: HIV/AIDS Sufferers by Age Group in Banjarmasin City for the Period 2012 - 2018

\begin{tabular}{llllllll}
\hline Age Group & $\mathbf{2 0 1 2}$ & $\mathbf{2 0 1 3}$ & $\mathbf{2 0 1 4}$ & $\mathbf{2 0 1 5}$ & $\mathbf{2 0 1 6}$ & $\mathbf{2 0 1 7}$ & $\mathbf{2 0 1 8}$ \\
\hline s 1 years & 0 & 0 & 0 & 0 & 0 & 0 & 0 \\
1 - 4 years & 1 & 3 & 4 & 3 & 1 & 5 & 3 \\
5 - 14 years & 0 & 0 & 3 & 0 & 0 & 1 & 0 \\
15 - 19 years & 0 & 3 & 2 & 1 & 4 & 7 & 3 \\
2 - 29 years & 25 & 22 & 31 & 48 & 57 & 78 & 48 \\
30 - 39 years & 34 & 18 & 29 & 30 & 54 & 59 & 43 \\
$40-49$ years & 10 & 7 & 20 & 14 & 20 & 20 & 26 \\
50 - 59 years & 6 & 0 & 1 & 6 & 6 & 12 & 13 \\
$\geq$ 60 years & 0 & 2 & 1 & 1 & 2 & 0 & 0 \\
Total & 76 & 55 & 91 & 103 & 144 & 182 & 136 \\
\hline
\end{tabular}

Source: 2019 Banjarmasin City Health Office (processed by researchers)

The number of people registered as HIV / AIDS sufferers was formally determined from the Banjarmasin City Health Office Report, 2019. The picture above is an explanation of the increasing number of HIV / AIDS cases in Banjarmasin City in the period 2012-2018. The increase in cases of HIV / AIDS in the city of Banjarmasin from 2012 amounted to 76 people and continues to increase until 2018 by 136 people, this has contributed to an increase in the number of sick people and increased the number of unemployed people due to the inability of HIV / AIDS sufferers to carry out activities. HIV / AIDS prevention efforts in the city of Banjarmasin will not be separated from the national HIV / AIDS response, while the national government's HIV / AIDS prevention efforts have been included in the National AIDS Strategy in 2015 - 2019. In addition, the National Government has also made efforts to accelerate HIV prevention / AIDS through the acceleration / Fast-track program which is an intensive and comprehensive control effort suitable for areas of high prevalence.

The Suitability of HIV/AIDS Control Programs with Community Needs: Regional Regulation Number 11 of 2012 concerning HIV / AIDS Prevention in the city of Banjarmasin was made to achieve the stated goals. Efforts to prevent HIV / AIDS require the spread of information to the whole community, especially to the productive age group because the high number of HIV / AIDS sufferers in the city of Banjarmasin is focused on the productive age group. This is also based on the findings of the fact that policy implementation has not been carried out in accordance with the contents and objectives of the local regulations that have been issued. This requires communication and information focused on the target group, and also the need for the use of digital media in disseminating information. Communication through digital media is very appropriate, considering the target group is a productive age community which is very close to technological progress. With the goals set in the regional regulation with the intention to be able to reduce the rate of transmission of HIV / AIDS cases in the city of Banjarmasin. The implementation of HIV / AIDS prevention policy cannot be 
separated from the values and culture that exists in the community this will lead to conflict both personally and in groups in the community. HIV / AIDS prevention efforts in the city of Banjarmasin that have been implemented are as follows:

\section{Figure 1}

\section{Gambar 6.3 Upaya Pencegahan HIV/AIDS}

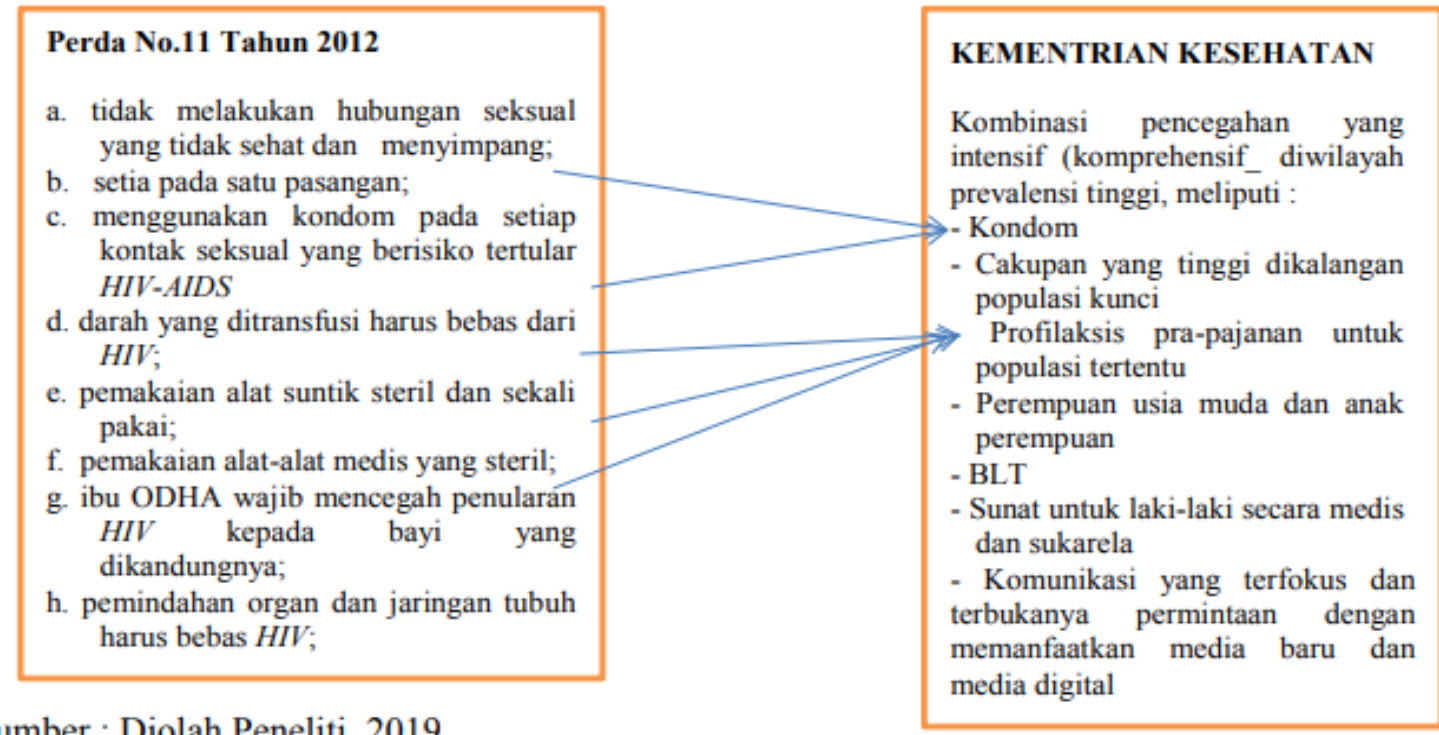

To find out whether the policy implementation is carried out appropriately or not, we must know the suitability of the program with the needs of the target group (Ripley, 1986). Delay or mismatch in the implementation of policies with the needs of the target will cause failure in achieving the stated policy objectives. Ripley also mentioned that what affects the implementor's compliance to run the policy is the complexity of a program that is seen from the rules of the program and seen from the dynamic implementation instructions. In addition, the compliance of the implementer to implement prevention programs is one that supports the successful implementation of policies (Ripley, 1986). In this case the HIV / AIDS prevention policy in the city of Banjarmasin does not yet have a mayor union or technical guidelines for the implementation of HIV / AIDS prevention so the instructions for implementing the HIV / AIDS prevention policy cannot be said to be successful. HIV / AIDS prevention efforts based on regional regulation Number 11 of 2012 in Banjarmasin City aims to control AIDS in Banjarmasin City. If seen from the prevention efforts that are carried out are still low, HIV / AIDS prevention efforts carried out only in general as a routine carried out like the previous program and not focused on the largest AIDS community target group, namely MSM. The compliance of HIV / AIDS prevention policy implementers in Banjarmasin City in implementing regional regulation number 11 of 2012 in Banjarmasin City is still low.

This means that more attention needs to be given to the MSM community, because apart from the MSM community it is still veiled and the possibility of spreading is higher because sexual activities can be carried out to fellow men and women alike. This situation shows that the HIV / AIDS prevention program in the MSM community has not yet become the main consideration in efforts to prevent HIV / AIDS. Therefore, the prevention program implemented by the Ministry of Health, namely fast-track or efforts to accelerate the high coverage among key populations can be applied in the city of Banjarmasin. In addition, prevention programs carried out by the government are not focused on one organization so it will be difficult to monitor the success of a program. Therefore we need an organization or institution that focuses on coordinating prevention, so far the role has been carried out by the AIDS Commission, but due to limited funds, the AIDS Commission in the city of Banjarmasin since the end of 2018 has not carried out activities in HIV / AIDS prevention efforts. This is in addition because the local regulation has not been socialized so that the 
implementer concerned does not feel responsible. In addition, also because it considers that HIV / AIDS prevention efforts are still not urgent (priority) because there are still more priority agency programs. The low compliance of the implementer is also due to the opinion of stakeholders that if the case of HIV / AIDS is raised it will affect the position of Banjarmasin City as a recipient of Adipura.

\section{Conclusion}

Based on the results of the analysis that has been presented, it can be concluded that the Implementation of the HIV/AIDS Control Policy in the City of Banjarmasin has been followed up with the issuance of regional regulations concerning HIV/AIDS control. However, there are still gaps in the implementation making efforts to control HIV/AIDS seem ineffective. This is also based on the findings of the fact that policy implementation has not been carried out in accordance with the contents and objectives of the local regulations that have been issued. In addition, the implementation of HIV/AIDS control policies is not in accordance with the needs of the community and this policy has not touched the high risk community in the city of Banjarmasin. Another fact is the lack of participation of many actors and coordination support in efforts to control HIV/AIDS. However, this research has revealed empirical facts and phenomena from the actions of the Banjarmasin city government in implementing HIV/AIDS control policies. In view of these findings, the recommendations of this study are presented for consumption by policy makers in Banjarmasin City and non-governmental organizations engaged in efforts to control HIV/AIDS. There must be government efforts for HIV/AIDS control programs that are appropriate to the needs of the community. And the need for a multisectoral approach to carrying out efforts to control HIV/AIDS.

Thank-You Note: Thank you to the Provincial Government of South Kalimantan for your support of this research. Thank you to the Banjarmasin city government and related agencies for their support of the smooth running of this research.

Author's Contributions: All co-authors have made a substantial contribution to the manuscript they revised it critically for important content and approved the final version.

Author's Affiliations: Researcher at Regional Research and Development Agency of Kalimantan Province Chandidate Doctor at Doctoral Public Administration, Diponegoro University Semarang Indonesia.

\section{References}

Creswell, J. (2014). Research Design Qualitative, and Mixed Approach (Fourth edition).

SAGE Publication South Kalimantan Provincial Health. (2017). 2015 and 2016 annual activity report. South Kalimantan Provincial.

Banjarmasin City Health. (2017). Annual activity report. South Kalimantan Province.

Banjarmasin City Health. (2019). Annual activity report. South Kalimantan Province.

South Kalimantan Provincial Health. (2014). 2014 Data Pocket Book. South Kalimantan Province.

Directorate General of Disease Management \& Environmental Health Ministry of Health Republic of Indonesia (2016). Technical Guidelines for HIV / AIDS Control Program and PIMS First Level Health Facilities.

Goggin, M. (1990). Implementation, Theory and Practice. Toward a Third Generation. Forasmann and Company. USA

Hajer, M., A. \& Wagenar. (2003). Deliberative Policy Analysis: Understanding Governance in the Network Society. Cambridge, New York

Kabayakgosi, M. (2008). Beyond Public Administration? HIV/AIDS Policy Networks and the Transformation of Public Administration in Botswana

AIDS Commission in ASIA. (2015). Independent Commission Redefining AIDS in ASIA - Crafting an Effective Response.

National HIV and AIDS Commission. (2015). National Strategy and Action Plan 2015-2019: HIV and AIDS Prevention in Indonesia.

AIDS Commission. (2015). Research Report: Overview of Community Sector Response to HIV / AIDS Control in Indonesia.

South Kalimantan Province AIDS Control Commission. (2016). Performance Report on the AIDS Commission. 


\section{Journal of Social and Development Sciences (ISSN 2221-1152)}

Vol. 10, No. 3, pp. 22-29, September 2019

Banjarmasin City AIDS Commission. (2019). Narrative Report on NFM Phase Global Fund Support Program Quarter 8 Semester, 4. The Indonesian Ministry of Health. Health Law No. 36 of 2009 concerning Health

Ripley, R. B. (1986). Policy Analysis in Political Science. Chicago: Nelson-Hall

Ritzer, G. J. \& Douglas. (2008). Teori Sosiologi Modern. Kencana. Jakarta

Parsons, W. (2014). Public Policy : An introduction to the theory and practice of policy analysis. Edition reprinted. Edward Elgar. Cheltenham, UK. Lyme,US.

Parsons, W. (1997). Public Policy : An introduction to the theory and practice of policy analysis. Edition reprinted. Edward Elgar. Cheltenham, UK. Lyme,US.

Pacton, J. \& Stephen. (2007). Challenges to the Meaningful involvement of HIV-positive people in the response to HIV/AIDS in Cambodia, India and Indonesia. Regional Regulation of the City of banj No. 11 of 2012 concerning HIV-AIDS Control in the City of Banjarmasin Presidential Regulation No.75 of 2006 concerning the National AIDS Commission.

Suwitri, S., Afriani, H., Sagala, R. \& Slamet, S. (2009). Implementation of HIV and AIDS Management Policies in Central Java (Study of Regional Regulation of Central Java Province Number 5 Year 2009).

UNAIDS. (2013). HIV Estimates 2012. GARPR 2013

UNAIDS. (2014). On the Fast-Track to end AIDS.

UNAIDS. (2004). Report on Global HIV/AIDS Epidemic: $4^{\text {th }}$ Global Report. UNAIDS. Geneva

Van, M., Donal, S., Carl, E. \& Van, H. (1975). The Policy Implementation Process: A Conceptual Framework, Administration \& Society, 6. 